\title{
Gene mutations resulting in the development of ARVC/D could affect cells of the cardiac conduction system
}

\author{
Sebastian Pieperhoff* \\ British Heart Foundation Centre for Cardiovascular Science, Queen's Medical Research Institute, University of Edinburgh, Edinburgh, Scotland, UK
}

\section{Edited by:}

Ruben Coronel, Academic Medical

Center, Netherlands

\section{Reviewed by:}

Bas Boukens, Academic Medical Center, Netherlands

Tamara Koopmann, Academic Medical

Center, Netherlands

\section{*Correspondence:}

Sebastian Pieperhoff, British Heart Foundation Centre for Cardiovascular Science, Queen's Medical Research Institute, University of Edinburgh, 47 Little France Crescent, Edinburgh, Scotland, UK

e-mail: s.pieperhoff@gmail.com
In contrast to epithelial cells, cardiomyocytes are connected by complex hybrid-type adhering junctions, termed composite junctions (areae compositae). Composite junctions are found to be composed of typical desmosomal as well as adherens junction proteins. Therefore, in adult mammalian cardiomyocytes desmosomal proteins are not restricted to the relatively small desmosomes but are indirectly involved in anchoring the myofibrillar actin filaments. Subsequent investigations revealed that the formation of composite junctions is a rather late event during mammalian heart development and vertebrate heart evolution. Nascent, more round shaped cardiomyocytes of early developmental stages are connected by desmosomes and separate adherens junctions quite similar to cells of epithelial origin. During progression of development both types of adhering junctions seem to gradually fuse at the two poles of the mature mammalian cardiomyocytes to establish the hybridtype composite junctions. Recently, we demonstrated that the specialized cardiomyocytes of the cardiac conduction system exhibit high amounts of desmosomes, not fully established composite junctions and adherens junctions. This underlines the fact that cells of the cardiac conduction system are known to resemble cardiomyocytes in their nascent state and do not undergo working myocardial differentiation. However, the astonishing high amount of desmosomal protein containing adhering junctions connecting, e.g., Purkinje fibers raises the possibility that pacemaker and conductive tissue may be affected by desmosomal gene mutations in ARVC/D patients.

Keywords: desmosome, area composita, heart, desmosomal gene mutation, conduction system, ARVC/D

\section{EFFECTS OF MUTATIONS IN GENES ENCODING FOR CARDIOMYOCYTE ADHERING JUNCTION COMPONENTS}

Desmosomes and fasciae adhaerentes (sing., fascia adhaerens), the latter also termed adherens junctions are responsible for cellcell adhesion and are often subsumed under the collective term adhering junctions. In various epithelia, like in the multistratified skin epithelium, desmosomes, and adherens junctions are distinct structures with only few shared components, such as, e.g., plakoglobin (Cowin et al., 1986). Desmosomes anchor the cytoskeletal intermediate filaments and fasciae adhaerentes the cytoskeletal actin microfilaments (Franke, 2009; Dubash and Green, 2011). In the heart things are quite different and more complex. Adult mammalian cardiomyocytes are for the most part connected by adhering junctions termed areae compositae (sing., area composita) or composite junctions to highlight their hybrid character (Franke et al., 2006, 2009; Pieperhoff et al., 2010a). Composite junctions consist of both, typical desmosomal and typical adherens junction proteins (Franke et al., 2006; Pieperhoff et al., 2010a). In composite junctions desmosomal proteins are therefore indirectly involved in supporting the myofibrillar actin anchorage in N-cadherin mediated cell-cell adhesion complexes (Goossens et al., 2007).

Today it is generally accepted that arrhythmogenic right ventricular cardiomyopathy/dysplasia (ARVC/D) is in most of the cases caused by mutations in desmosomal genes. Disease causing mutations have been found in genes encoding for the desmosomal plaque components plakophilin-2, desmoplakin, and plakoglobin and the transmembrane desmosomal cadherins desmoglein- 2 and desmocollin-2 (see, e.g., Rampazzo et al., 2002; Norman et al., 2005; Pilichou et al., 2006; Thiene et al., 2007; for further references please see Rickelt and Pieperhoff, 2012). Although rare, mutations in some non-desmosomal proteins such as, desmin (see Figure 1), transforming growth factor- $\beta 3$ (TGFB3), transmembrane protein 43 (TMEM43), ryanodine receptor 2 (RYR2), lamins A and C, striatin and titin have also been associated with ARVC/D development (Rampazzo et al., 1995; Beffagna et al., 2005; Merner et al., 2008; Klauke et al., 2010; Meurs et al., 2010; Quarta et al., 2011; Taylor et al., 2011). ARVC/D is characterized by a progressive replacement of contractile heart muscle tissue by fibrotic and fat tissue ("fibrofatty replacement") and severe arrhythmogenesis often followed by sudden cardiac mortality. Fibrofatty replacement was often but not exclusively found in the right ventricle (Bauce et al., 2005; Lindstrom et al., 2005; Thiene et al., 2007). Homozygous mutations in plakoglobin cause a syndromic disease form called "Naxos disease" involving skin and hair abnormalities in addition to the ARVC/D-type fibrofatty replacement of the myocardium (Protonotarios et al., 2001).

Functional alterations in ARVC/D most likely include alterations in gap junctions and sodium channels as a result from adhering junction defects (Kaplan et al., 2004; Sato et al., 2009, 2011). Furthermore, suppressed Wnt-signaling by nuclear plakoglobin may be involved in fibrofatty replacement and ARVC/D phenotype development (Garcia-Gras et al., 2006; MacRae et al., 
2006; Hirschy et al., 2010; Lombardi et al., 2011). In earlier investigations, cell contacts have been found to be an independent factor for cardiomyocyte survival in vitro (Clark et al., 1998) showing the general importance of these structures beside their important role in cell-cell adhesion.

Overexpression of mutant desmosomal genes or introduction of mutant desmosomal genes in mice (Pilichou et al., 2009) and other animal model systems (zebrafish) will help further to understand ARVC/D disease development and treatment (Macrae, 2010; Fabritz et al., 2011).

Recently, screening for novel candidates of ARVC/D causing genes have been for the first time extended to typical fascia adhaerens components, yet without striking results (Christensen et al., 2011). However, many other candidate genes, localized in the composite junctions within the intercalated disk may be included in future screenings (e.g., Kargacin et al., 2006; Otten et al., 2010; Seeger et al., 2010). Hopefully, this will improve molecular diagnostics, genetic testing, and genetic management of this disease (Fressart et al., 2010).

\section{POSSIBLE EFFECTS OF ARVC/D CAUSING GENE MUTATIONS ON CELLS OF THE CARDIAC CONDUCTION SYSTEM}

In the higher vertebrate heart muscle the rhythmic contraction of single cardiomyocytes is secured by a hierarchical system which includes the cardiac conduction system composed of pacemaker and conductive tissue. Pacemaker and conductive tissue consists of specialized cardiomyocytes which did not underwent working myocardial differentiation (Christoffels et al., 2010). Cells of the cardiac conduction system are insulated by connective tissue from the working myocardium in some areas of the heart (see Figure 1; see also, Anderson et al., 2009; Pieperhoff et al., 2010b). Electrical impulses are generated by cells of the sinoatrial (SA) node and travel to the atrioventricular (AV) node (Bakker et al., 2010). The conduction velocity is greatly reduced in the AV node to allow the atrium to contract before the ventricle (Mamlin and Fisch, 1965). The fast conduction system within the ventricle includes the bundles of His (1893), the right and left bundle branches (RBB, LBB) on either side of the ventricular septum and the meshwork of Purkinje fibers (Purkyne, 1845; Tawara, 1906; Shimada et al., 2004; Miquerol et al., 2011).

Pathological alterations in the cardiac conduction system have been described to cause sudden cardiac death before (e.g., Thiene et al., 1983) but never been found nor described in cases of ARVC/D. However, risk stratification of ARVC/D patients using ECG analyses revealed that "prolonged PR interval, prolonged QRS in lead VI, and presence of bundle branch block were predictors for adverse outcome" (Lemola et al., 2005).

Conductive cells have been found to be connected by a relatively high density of desmosomal protein containing desmosomes and composite junctions (Pieperhoff et al., 2010b). Cell contacts of conductive cells resemble adhering junctions of nascent cardiomyocytes (Pieperhoff and Franke, 2007; Pieperhoff et al., 2010b). Desmocollin-2 and desmoplakin (see Figure 2) and all other desmosomal as well as adherens junction components involved in connecting cardiomyocytes can be found in adhering junctions of Purkinje fiber cells (Pieperhoff et al., 2010b). This is why, mutations in desmosomal (and non-desmosomal) genes resulting

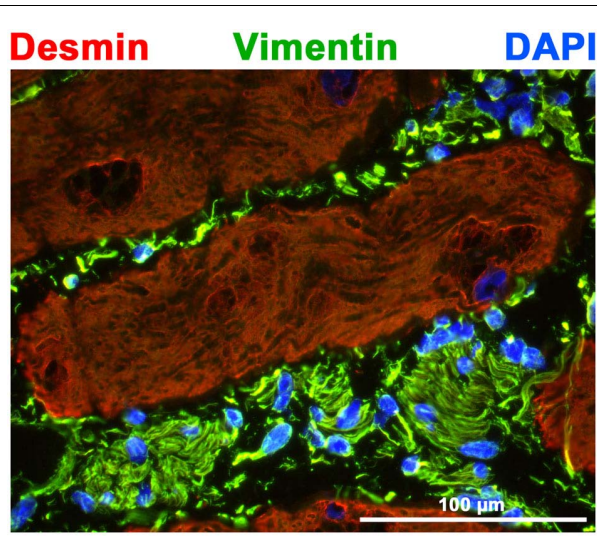

FIGURE 1 | Shown is a cryostat cross-section through ovine Purkinje fibers. Double label immunofluorescence microscopy was performed with antibodies to desmin (red) and vimentin (green) in addition to nuclear DAPI staining (blue). Note that the insulating connective tissue is strongly positive for vimentin, whereas Purkinje fibers are positive for desmin similar to cardiomyocytes of the working myocardium. For experimental details please see Pieperhoff et al. (2010b).

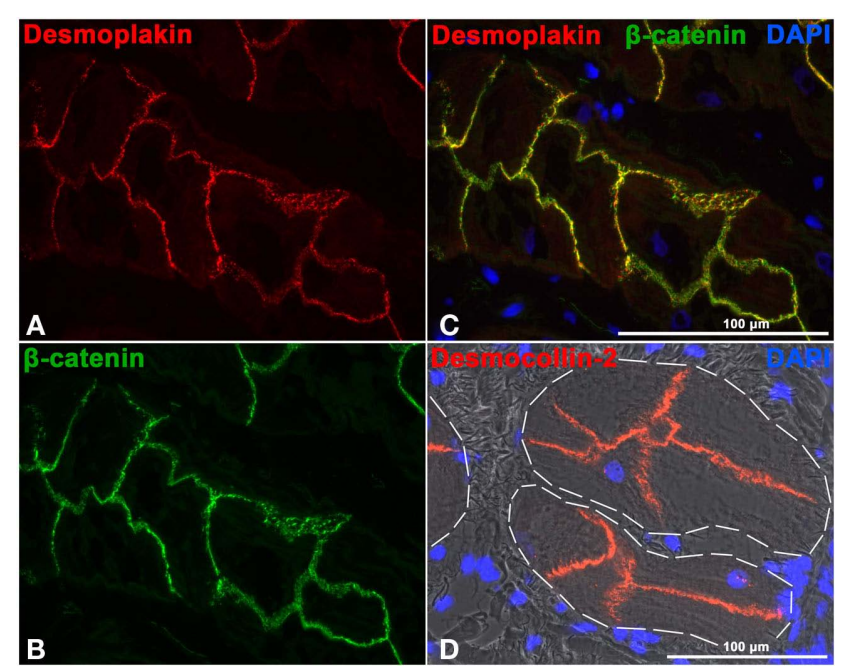

FIGURE 2 | Cryostat sections through ovine (A-C) and bovine (D) Purkinje fibers. (A-C) Double label immunofluorescence microscopy with antibodies to desmoplakin [red (A) and $\beta$-catenin green (B)]. The overlay of (A) and (B) is shown in (C) in addition to nuclear DAPI staining (blue). Note the often dotted staining pattern but high abundance of the desmosomal plaque component desmoplakin in conductive cells of the Purkinje fibers. (D) Desmocollin-2 antibody labeling (red) and DAPI staining (blue) merged with the phase contrast image. The white dashed lines demarcate the border between conductive tissue and insulating connective tissue. See also Pieperhoff et al. (2010b).

in the described defects in the myocardium could affect cells of the cardiac conduction system similarly. This could then contribute to severe arrhythmogenesis in ARVC/D patients and may explain why the presence of left bundle branch blocks in ECG analyses has been found to be a predictor for the adverse outcome of the disease (Lemola et al., 2005). Possible disease mechanisms could 
include cell adhesion defects, alterations in gap junction localization and function, resulting conduction disturbance and fibrofatty replacement of cardiomyocytes of the conduction system as similarly described in cardiomyocytes of the working myocardium (Norgett et al., 2000; Norman et al., 2005; MacRae et al., 2006; Herren et al., 2009; Sato et al., 2011).

\section{SUMMARY AND CONCLUSION}

Cardiomyocytes of the working myocardium and of the cardiac conduction system share many similarities. The high abundance of desmosomal protein containing adhering junctions connecting cardiomyocytes of the conduction system raises the possibility that conductive and pacemaker tissue might be affected by desmosomal gene mutations in cases of ARVC/D. Even minor alterations in

\section{REFERENCES}

Anderson, R. H., Yanni, J., Boyett, M. R., Chandler, N. J., and Dobrzynski, H. (2009). The anatomy of the cardiac conduction system. Clin. Anat. 22, 99-113.

Bakker, M. L., Moorman, A. F., and Christoffels, V. M. (2010). The atrioventricular node: origin, development, and genetic program. Trends Cardiovasc. Med. 20, 164-171.

Bauce, B., Basso, C., Rampazzo, A., Beffagna, G., Daliento, L., Frigo, G., Malacrida, S., Settimo, L., Danieli, G., Thiene, G., and Nava, A. (2005). Clinical profile of four families with arrhythmogenic right ventricular cardiomyopathy caused by dominant desmoplakin mutations. Eur. Heart J. 26, 1666-1675.

Beffagna, G., Occhi, G., Nava, A., Vitiello, L., Ditadi, A., Basso, C., Bauce, B., Carraro, G., Thiene, G., Towbin, J. A., Danieli, G. A., and Rampazzo, A. (2005). Regulatory mutations in transforming growth factor-beta3 gene cause arrhythmogenic right ventricular cardiomyopathy type 1. Cardiovasc. Res. 65, 366-373.

Christensen, A. H., Benn, M., TybjaergHansen, A., Haunso, S., and Svendsen, J. H. (2011). Screening of three novel candidate genes in arrhythmogenic right ventricular cardiomyopathy. Genet. Test. Mol. Biomarkers $15,267-271$.

Christoffels, V. M., Smits, G. J., Kispert, A., and Moorman, A. F. (2010). Development of the pacemaker tissues of the heart. Circ. Res. 106, 240-254.

Clark, W. A., Decker, M. L., BehnkeBarclay, M., Janes, D. M., and Decker, R. S. (1998). Cell contact as an independent factor modulating cardiac myocyte hypertrophy and survival in long-term primary culture. J. Mol. Cell. Cardiol. 30, 139-155.
Cowin, P., Kapprell, H. P., Franke, W. W., Tamkun, J., and Hynes, R. O. (1986). Plakoglobin: a protein common to different kinds of intercellular adhering junctions. Cell 46, 1063-1073.

Dubash, A. D., and Green, K. J. (2011). Desmosomes. Curr. Biol. 21, R529R531.

Fabritz, L., Hoogendijk, M. G., Scicluna, B. P., van Amersfoorth, S. C., Fortmueller, L., Wolf, S., Laakmann, S., Kreienkamp, N., Piccini, I., Breithardt, G., Noppinger, P. R., Witt, H., Ebnet, K., Wichter, T., Levkau, B., Franke, W. W., Pieperhoff, S., de Bakker, J. M., Coronel, R., and Kirchhof, P. (2011). Load-reducing therapy prevents development of arrhythmogenic right ventricular cardiomyopathy in plakoglobindeficient mice. J. Am. Coll. Cardiol. $57,740-750$.

Franke, W. W. (2009). Discovering the molecular components of intercellular junctions - a historical view. Cold Spring Harb. Perspect. Biol. 1, a003061.

Franke, W. W., Borrmann, C. M., Grund, C., and Pieperhoff, S. (2006). The area composita of adhering junctions connecting heart muscle cells of vertebrates. I. Molecular definition in intercalated disks of cardiomyocytes by immunoelectron microscopy of desmosomal proteins. Eur. J. Cell Biol. 85, 69-82.

Franke, W. W., Rickelt, S., Barth, M., and Pieperhoff, S. (2009). The junctions that don't fit the scheme: special symmetrical cell-cell junctions of their own kind. Cell Tissue Res. 338, 1-17.

Fressart, V., Duthoit, G., Donal, E., Probst, V., Deharo, J. C., Chevalier, P., Klug, D., Dubourg, O., Delacretaz, E., Cosnay, P., Scanu, P., Extramiana, F., Keller, D., Hidden-Lucet, F., Simon, F., Bessirard, V., RouxBuisson, N., Hebert, J. L., Azarine, A.,

cells of the cardiac conduction system could contribute to severe arrhythmogenesis in ARVC/D patients.

\section{ACKNOWLEDGMENTS}

I thank the German Science Foundation (DFG) for funding of a postdoctoral fellowship (Pi 869/1-1) and the British Heart Foundation (BHF) for subsequent funding within the BHF Centres of Research Excellence (BHF CoRE). Special thanks go to Prof. Werner Franke (German Cancer Research Center, Heidelberg, Germany), Prof. John Mullins, Dr. Martin Denvir, and Dr. Gillian Gray (QMRI, BHF Centre for Cardiovascular Science, Edinburgh, UK), and to Prof. Calum MacRae (Brigham and Women's Hospital, Harvard Medical School, Boston, MA, USA) for support and scientific discussions.

Casset-Senon, D., Rouzet, F., Lecarpentier, Y., Fontaine, G., Coirault, C. Frank, R., Hainque, B., and Charron, P. (2010). Desmosomal gene analysis in arrhythmogenic right ventricular dysplasia/cardiomyopathy: spectrum of mutations and clinical impact in practice. Europace 12 861-868.

Garcia-Gras, E., Lombardi, R., Giocondo, M. J., Willerson, J. T., Schneider, M. D., Khoury, D. S., and Marian, A. J. (2006). Suppression of canonical Wnt/beta-catenin signaling by nuclear plakoglobin recapitulates phenotype of arrhythmogenic right ventricular cardiomyopathy. $J$. Clin. Invest. 116, 2012-2021.

Goossens, S., Janssens, B., Bonne, S., De Rycke, R., Braet, F., van Hengel, J., and van Roy, F. (2007). A unique and specific interaction between alphaT-catenin and plakophilin-2 in the area composita, the mixedtype junctional structure of cardiac intercalated discs. J. Cell Sci. 120, 2126-2136.

Herren, T., Gerber, P. A., and Duru, F. (2009). Arrhythmogenic right ventricular cardiomyopathy/dysplasia: a not so rare "disease of the desmosome" with multiple clinical presentations. Clin. Res. Cardiol. 98, 141-158.

Hirschy, A., Croquelois, A., Perriard, E., Schoenauer, R., Agarkova, I., Hoerstrup, S. P., Taketo, M. M., Pedrazzini, T., Perriard, J. C., and Ehler, E. (2010). Stabilised beta-catenin in postnatal ventricular myocardium leads to dilated cardiomyopathy and premature death. Basic Res. Cardiol. 105, 597-608.

His, J. W. (1893). The story of the atrioventricular bundle with remarks concerning embryonic heart activity with remarks concerning embryonic heart movement in the adult. Arb. Med. Klin. Leipzig 4, 289-318.
Kaplan, S. R., Gard, J. J., Protonotarios, N., Tsatsopoulou, A., Spiliopoulou, C., Anastasakis, A., Squarcioni, C. P., McKenna, W. J., Thiene, G., Basso, C., Brousse, N., Fontaine, G., and Saffitz, J. E. (2004). Remodeling of myocyte gap junctions in arrhythmogenic right ventricular cardiomyopathy due to a deletion in plakoglobin (Naxos disease). Heart Rhythm 1, 3-11.

Kargacin, G. J., Hunt, D., Emmett, T., Rokolya, A., McMartin, G. A., Wirch, E., Walsh, M. P., Ikebe, M., and Kargacin, M. E. (2006). Localization of telokin at the intercalated discs of cardiac myocytes. Arch. Biochem. Biophys. 456, 151-160.

Klauke, B., Kossmann, S., Gaertner, A., Brand, K., Stork, I., Brodehl, A., Dieding, M., Walhorn, V., Anselmetti, D., Gerdes, D., Bohms, B., Schulz, U., Zu Knyphausen, E., Vorgerd, M., Gummert, J., and Milting, H. (2010). De novo desminmutation N116S is associated with arrhythmogenic right ventricular cardiomyopathy. Hum. Mol. Genet. 19, 4595-4607.

Lemola, K., Brunckhorst, C., Helfenstein, U., Oechslin, E., Jenni, R., and Duru, F. (2005). Predictors of adverse outcome in patients with arrhythmogenic right ventricular dysplasia/cardiomyopathy: long term experience of a tertiary care centre. Heart 91, 1167-1172.

Lindstrom, L., Nylander, E., Larsson, H. and Wranne, B. (2005). Left ventricular involvement in arrhythmogenic right ventricular cardiomyopathy - a scintigraphic and echocardiographic study. Clin. Physiol. Funct. Imaging 25, 171-177.

Lombardi, R., da Graca CabreiraHansen, M., Bell, A., Fromm, R. R., Willerson, J. T., and Marian, A. J. (2011). Nuclear plakoglobin is essential for differentiation of cardiac progenitor cells to 
adipocytes in arrhythmogenic right ventricular cardiomyopathy. Circ. Res. 109, 1342-1353.

Macrae, C. A. (2010). Cardiac arrhythmia: in vivo screening in the zebrafish to overcome complexity in drug discovery. Expert Opin. Drug Discov. 5, 619-632.

MacRae, C. A., Birchmeier, W., and Thierfelder, L. (2006). Arrhythmogenic right ventricular cardiomyopathy: moving toward mechanism. J. Clin. Invest. 116, 1825-1828.

Mamlin, J. J., and Fisch, C. (1965). Sustained atrioventricular conduction delay due to interpolated ventricular premature systole. Am. J. Cardiol. 16, 765-766.

Merner, N. D., Hodgkinson, K. A., Haywood, A. F., Connors, S., French, V. M., Drenckhahn, J. D., Kupprion, C., Ramadanova, K., Thierfelder, L., McKenna, W., Gallagher, B., Morris-Larkin, L., Bassett, A. S., Parfrey, P. S., and Young, T. L. (2008). Arrhythmogenic right ventricular cardiomyopathy type 5 is a fully penetrant, lethal arrhythmic disorder caused by a missense mutation in the TMEM43 gene. Am. J. Hum. Genet. 82, 809-821.

Meurs, K. M., Mauceli, E., Lahmers, S., Acland, G. M., White, S. N., and Lindblad-Toh, K. (2010). Genomewide association identifies a deletion in the 3' untranslated region of striatin in a canine model of arrhythmogenic right ventricular cardiomyopathy. Hum. Genet. 128, 315-324.

Miquerol, L., Beyer, S., and Kelly, R. G. (2011). Establishment of the mouse ventricular conduction system. Cardiovasc. Res. 91, 232-242.

Norgett, E. E., Hatsell, S. J., CarvajalHuerta, L., Cabezas, J. C., Common, J., Purkis, P. E., Whittock, N., Leigh, I. M., Stevens, H. P., and Kelsell, D. P. (2000). Recessive mutation in desmoplakin disrupts desmoplakinintermediate filament interactions and causes dilated cardiomyopathy, woolly hair and keratoderma. Hum. Mol. Genet. 9, 2761-2766.

Norman, M., Simpson, M., Mogensen, J., Shaw, A., Hughes, S., Syrris, P., Sen-Chowdhry, S., Rowland, E., Crosby, A., and McKenna, W. J. (2005). Novel mutation in desmoplakin causes arrhythmogenic left ventricular cardiomyopathy. Circulation 112, 636-642.

Otten, J., van der Ven, P. F., Vakeel, P., Eulitz, S., Kirfel, G., Brandau, O., Boesl, M., Schrickel, J. W., Linhart,
M., Hayess, K., Naya, F. J., Milting, H., Meyer, R., and Furst, D. O. (2010). Complete loss of murine Xin results in a mild cardiac phenotype with altered distribution of intercalated discs. Cardiovasc. Res. 85, 739-750.

Pieperhoff, S., Barth, M., Rickelt, S., and Franke, W. W. (2010a). "Desmosomal molecules in and out of adhering junctions: normal and diseased states of epidermal, cardiac and mesenchymally derived cells," Desmosomes and Desmosomal Cadherin Function in Skin and Heart Diseases Advancements in Basic and Clinical Research," eds M. G. Mahoney, E. J. Müller, and P. J. Koch (New York: Hindawi), 11.

Pieperhoff, S., Borrmann, C. M., Grund, C., Barth, M., Rizzo, S., and Franke, W. W. (2010b). The area composita of adhering junctions connecting heart muscle cells of vertebrates. VII. The different types of lateral junctions between the special cardiomyocytes of the conduction system of ovine and bovine hearts. Eur. J. Cell Biol. 89, 365-378.

Pieperhoff, S., and Franke, W. W. (2007). The area composita of adhering junctions connecting heart muscle cells of vertebrates. IV. Coalescence and amalgamation of desmosomal and adhaerens junction components - late processes in mammalian heart development. Eur. J. Cell Biol. 86, 377-391.

Pilichou, K., Nava, A., Basso, C., Beffagna, G., Bauce, B., Lorenzon, A., Frigo, G., Vettori, A., Valente, M., Towbin, J., Thiene, G., Danieli, G. A., and Rampazzo, A. (2006). Mutations in desmoglein-2 gene are associated with arrhythmogenic right ventricular cardiomyopathy. Circulation 113, 1171-1179.

Pilichou, K., Remme, C. A., Basso, C., Campian, M. E., Rizzo, S., Barnett, P., Scicluna, B. P., Bauce, B., van den Hoff, M. J., de Bakker, J. M., Tan, H. L., Valente, M., Nava, A., Wilde, A. A., Moorman, A. F., Thiene, G., and Bezzina, C. R. (2009). Myocyte necrosis underlies progressive myocardial dystrophy in mouse dsg2-related arrhythmogenic right ventricular cardiomyopathy. J. Exp. Med. 206, 1787-1802.

Protonotarios, N., Tsatsopoulou, A., and Fontaine, G. (2001). Naxos disease: keratoderma, scalp modifications, and cardiomyopathy. J. Am. Acad. Dermatol. 44, 309-311.
Purkyne, J. E. (1845). Mikroskopischneurologische Beobachtungen. Arch. Anat. Physiol. Wiss. Med. 12, 281-295.

Quarta, G., Syrris, P., Ashworth, M., Jenkins, S., Zuborne Alapi, K., Morgan, J., Muir, A., Pantazis, A., McKenna, W. J., and Elliott, P. M. (2011). Mutations in the Lamin A/C gene mimic arrhythmogenic right ventricular cardiomyopathy. Eur. Heart J. doi: 10.1093/eurheartj/ehr1451. [Epub ahead of print].

Rampazzo, A., Nava, A., Erne, P., Eberhard, M., Vian, E., Slomp, P., Tiso, N., Thiene, G., and Danieli, G. A. (1995). A new locus for arrhythmogenic right ventricular cardiomyopathy (ARVD2) maps to chromosome 1q42-q43. Hum. Mol. Genet. 4, 2151-2154.

Rampazzo, A., Nava, A., Malacrida, S., Beffagna, G., Bauce, B., Rossi, V., Zimbello, R., Simionati, B., Basso C., Thiene, G., Towbin, J. A., and Danieli, G. A. (2002). Mutation in human desmoplakin domain binding to plakoglobin causes a dominant form of arrhythmogenic right ventricular cardiomyopathy. Am. J. Hum. Genet. 71, 1200-1206.

Rickelt, S. and Pieperhoff, S. (2012). Mutations with pathogenic potential in proteins located in or at the composite junctions of the intercalated disk connecting mammalian cardiomyocytes: a reference thesaurus for arrhythmogenic cardiomyopathies as well as Naxos and Carvajal diseases. Cell Tiss. Res. doi 10.1007/s00441-012-1365-0

Sato, P. Y., Coombs, W., Lin, X. Nekrasova, O., Green, K. J., Isom, L. L., Taffet, S. M., and Delmar, M. (2011). Interactions between ankyrin-g, plakophilin-2, and connexin 43 at the cardiac intercalated disc. Circ. Res. 109, 193-201.

Sato, P. Y., Musa, H., Coombs, W., Guerrero-Serna, G., Patino, G. A., Taffet, S. M., Isom, L. L., and Delmar, M. (2009). Loss of plakophilin2 expression leads to decreased sodium current and slower conduction velocity in cultured cardiac myocytes. Circ. Res. 105, 523-526.

Seeger, T. S., Frank, D., Rohr, C., Will R., Just, S., Grund, C., Lyon, R., Ludde, M., Koegl, M., Sheikh, F., Rottbauer, W., Franke, W. W., Katus, H. A., Olson, E. N., and Frey, N. (2010). Myozap, a novel intercalated disc protein, activates serum response factor-dependent signaling and is required to maintain cardiac function in vivo. Circ. Res. 106, 880-890.

Shimada, T., Kawazato, H., Yasuda, A., Ono, N., and Sueda, K. (2004). Cytoarchitecture and intercalated disks of the working myocardium and the conduction system in the mammalian heart. Anat. Rec. A Discov. Mol. Cell. Evol. Biol. 280, 940-951.

Tawara, S. (1906). Das Reizleitungssystem des Säugetierherzens. Eine anatomisch-histologische Studie über das Atrioventrikularbündel und die Purkinjeschen Fäden. Jena: Verlag von Gustav Fisher.

Taylor, M., Graw, S., Sinagra, G., Barnes, C., Slavov, D., Brun, F., Pinamonti, B., Salcedo, E. E., Sauer, W., Pyxaras, S., Anderson, B., Simon, B., Bogomolovas, J., Labeit, S., Granzier, H., and Mestroni, L. (2011). Genetic variation in titin in arrhythmogenic right ventricular cardiomyopathyoverlap syndromes. Circulation 124 , 876-885.

Thiene, G., Corrado, D., and Basso, C. (2007). Arrhythmogenic right ventricular cardiomyopathy/dysplasia. Orphanet. J. Rare Dis. 2, 45.

Thiene, G., Pennelli, N., and Rossi, L. (1983). Cardiac conduction system abnormalities as a possible cause of sudden death in young athletes. Hum. Pathol. 14, 707-709.

Conflict of Interest Statement: The author declares that the research was conducted in the absence of any commercial or financial relationships that could be construed as a potential conflict of interest.

Received: 05 January 2012; accepted: 30 January 2012; published online: 17 February 2012.

Citation: PieperhoffS (2012) Gene mutations resulting in the development of $A R V C / D$ could affect cells of the cardiac conduction system. Front. Physio. 3:22. doi: 10.3389/fphys.2012.00022

This article was submitted to Frontiers in Cardiac Electrophysiology, a specialty of Frontiers in Physiology.

Copyright (c) 2012 Pieperhoff. This is an open-access article distributed under the terms of the Creative Commons Attribution Non Commercial License, which permits non-commercial use, distribution, and reproduction in other forums, provided the original authors and source are credited. 